\title{
LAND COVER TYPES AND THEIR EFFECT ON THE URBAN HEAT SIGNATURE OF UNIVERSITY CAMPUSES USING REMOTE SENSING
}

\author{
Adi Wibowo ${ }^{1,2^{*}}$, Khairulmaini Osman Salleh ${ }^{1}$ \\ ${ }^{1}$ Department of Geography, Faculty of Arts and Social Sciences, University of Malaya, Kuala Lumpur \\ 50603, Malaysia \\ ${ }^{2}$ Department of Geography, Faculty of Mathematics and Natural Sciences, Universitas Indonesia, \\ Kampus UI Depok, Depok 16424, Indonesia
}

(Received: January 2017 / Revised: May 2017 / Accepted: March 2018)

\begin{abstract}
The campus, as an educational area, has a variety of land cover with varying surface temperatures. Knowledge of land use in a localized urban environment and its effect on the Urban Heat Signature (UHS) of a university campus is insufficient, so it is essential to assess UHS-related localized urban environments. The objective of this study is to assess land cover and its effect on the UHS of two university campuses. The research used spatial-temporal analysis employing satellite images during the period 2013-2014. The areas studied were the University Malaya (UM) and University Indonesia (UI) campuses. The results show that the land cover of both university campuses has the same localized urban environment pattern. Based on Landsat 8 TIRS (100 $\mathrm{m}$ ground resolution) both university campuses had UHS profiles related to vegetation cover of $25-33^{\circ} \mathrm{C}$, with mean temperature $28^{\circ} \mathrm{C}$ is the lowest temperature, and building cover of $33-39^{\circ} \mathrm{C}$, with a mean temperature $35^{\circ} \mathrm{C}$, is the highest temperature, caused effect from Land cover types. Google Earth visual interpretation and digitalization provided the land cover based on $10 \mathrm{~m} \times 10 \mathrm{~m}$ vector square grids with their attributes validated by field survey. The research shows a trend of UHS change between 2013 and 2014, with the maximum temperature of $>30^{\circ} \mathrm{C}$ on the UM and UI Campuses with increased of temperature $1{ }^{\circ} \mathrm{C}$. The study concludes that the UHS behavior is an effect of its temporal relation with land cover, which is new knowledge on university campuses about localized urban environments.
\end{abstract}

Keywords: Land cover; Spatial and temporal analysis; Urban heat signature profiles

\section{INTRODUCTION}

In Southeast Asia, for example, Malaysia, observations in the past 20 years have noted a temperature increase of $0.5^{\circ} \mathrm{C}$ to $1.5^{\circ} \mathrm{C}$, in line with the intensity of land use change (Malaysian Meteorological Department, 2009). Urbanization has initiated alterations in the natural ecosystem become an urban landscape (Tran et al., 2006). Even though the increased temperature is a natural phenomenon in urban areas, but it could be a threat in tropical cities when the temperature is higher than $30^{\circ} \mathrm{C}$ (Tursilowati, 2008; Ichinose et al., 2008; Tursilowati et al., 2012). Such increased temperatures will impact on human life (Salleh \& Ghaffar, 2009; Johnson et al., 2012).

Land cover type as a representation of land use (Ren et al., 2012) can absorb and reradiate sun

\footnotetext{
*Corresponding author's email: adi.w@sci.ui.ac.id, Tel. +62 811848149

Permalink/DOI: https://dx.doi.org/10.14716/ijtech.v9i3.1932
} 
Radiation and generate urban heat (Wong \& Yu, 2005; Srivanit \& Hokao, 2013). In general, the urban land cover associated with buildings, roads and pavements, highways, green parks and also bare soil (Ahmad \& Hashim, 2007). Land cover type as climatic (temperature) characteristics of local climates. Temperature and land use/cover information, which allows monitoring of the urban environment and human activities, enhances our understanding of the urban environment (Asmat et al., 2003).

Urbanized areas have significantly higher daylight surface temperatures compared to those of surrounding rural areas with relatively more vegetation (Tran et al., 2006). Urbanized areas are associated with high temperatures, while green spaces are associated with low temperatures (de la Barrera et al., 2015) caused by urban surface temperature reflect from the solar radiation (Li et al., 2010). Urban areas, were the temperature higher in densely built cities, have different heat intensity ( $\mathrm{Su}$ et al., 2012), the other hand the urban heat phenomenon is a natural consequence related to the land cover type and solar radiation. (Kim \& Baik, 2005; Ichinose et al., 2008; Memon et al., 2009; Mirzaei \& Haghighat, 2010; Stewart \& Oke, 2012). Built-up surfaces in urban areas are related to high temperatures (Taha, 1997; Tran et al., 2006), while green surfaces with moist soil might reach a temperature of only $18^{\circ} \mathrm{C}$ (Gartland, 2008). According to Chen and Ng (2012), urban heat has become critical in zones where inadequate shading and green spaces are unable to intercept and balance the heat from direct solar gains (Srivanit \& Hokao, 2013). Urban air temperatures can be on average $2{ }^{\circ} \mathrm{C}$ higher than in rural areas (Taha, 1997) and the maximum surface temperatures are also associated with high-rise city core areas (Tran et al., 2006). According to Shahidan et al. (2012) and Tran et al. (2006), the highest outdoor thermal stress observed during bright sunny days with a calm wind in the summer season. However, in tropical climate zones, the most considerable thermal anxiety may occur during the yearly hot, dry periods at noon due to higher solar radiation exposure (Srivanit \& Hokao, 2013). Land cover in localized urban environments has natural consequences related to sun radiation which high-low temperature urban land cover is Urban Heat Signature.

Remote sensing techniques are beneficial and efficient in analyzing the relationship between land surface temperature and land cover in tropical regions (Asmat et al., 2003; Ahmad \& Hashim, 2007; Mirzaei \& Haghighat, 2010; Kuşcu \& Sengezer, 2011; Mallick et al., 2012; Tursilowati et al., 2012; Senayake et al., 2013; Rozentein et al., 2014; Roy et al., 2014). Thermal bands with spatial resolutions are retrieved from land satellites (Wong \& Yu, 2005; Wong et al., 2007; Tursilowati, 2008; Mirzaei \& Haghighat, 2010; Tursilowati et al., 2012, Wibowo, et al., 2013; Weng et al., 2014). Furthermore, LST retrieved from the thermal images can show that areas covered by vegetation and farmland have lower LST, while urban areas have much higher LST (Srivastava et al., 2009). Wong et al. (2007) concluded from thermal images that there was a reddish color of thermal distribution on and around buildings, that a greenish color appeared in high-density plantation areas, with a yellowish color between these areas. The colors in this research are also related to Mallick et al. (2012), who argue that the spatial distribution of land surface temperature is related to land cover distribution. LST is an essential factor in global change studies, heat balance, and as a control for climate change (Srivastava et al., 2009). This temperature information provides a powerful way to monitor the urban environment (Asmat et al., 2003).

University campuses are considered as cities on a smaller scale (Wong et al., 2007; Saadatian et al., 2013; Srivanit \& Hokao, 2013), due to their coverage area, population size and various complex activities (Srivanit \& Hokao, 2013). The accelerated rate of urban growth in tropical cities (Makaremi et al., 2012, Ren et al., 2012) and urban land cover will generate heat intensity (Srivanit \& Hokao, 2013). Nowadays, climate change has become the primary issue of global concern for university leaders (Suwartha \& Sari, 2013), who have realized the impact of university activities on the environment (Srivanit \& Hokao, 2013). University institutions have 
a responsibility to communities for creating better urban living (Srivanit \& Hokao, 2013; Wang et al., 2013). Within universities there exist many types of land cover, which exhibit different heat absorption and transmission capacities in their design and materials. The knowledge of land use as a localized urban environment and its effect on the urban heat signature (UHS) of university campuses is insufficient, so it is essential to assess UHS about localized urban environments. The objective of this study is to assess land cover and its effect on the UHS of two university campuses. The focus of the research is on the UHS of the University of Malaya and University of Indonesia, and the spatial and temporal behavior of urban heat on the two campuses.

\section{METHODOLOGY}

According to the introduction to the paper, campuses in a tropical area were chosen as the study region to answer the objectives of the research, these areas located at the University of Malaya (Malaysia) and University of Indonesia (Indonesia). The study uses LST from Landsat 8 TIRS (satellite image) data (Mirzaei \& Haghighat, 2010; Kuşcu \& Şengezer, 2011; Tursilowati et al., 2012; Senayake et al., 2013; Rozenstein et al., 2014; Roy et al., 2014). Landsat 8 had two thermal bands; this research used Band 10 to process becoming LST data, as according to Wang et al. (2015), and thermal band 11 has considerable data uncertainty (Wang et al., 2016). It is the latest series of the Landsat system, carrying two sensors: an Operational Land Imager (OLI) and Thermal Infrared Sensor (TIRS). This study mostly employed the TIRS sensor, which has two bands (TIR-1 and TIR-2), with 100-meter spatial resolution and 16-day temporal resolution. The limitation of using remote satellite sensing is cloud cover.

\subsection{Datasets}

The research started from the acquisition of data on the land cover using Google Earth data and validated survey ground truth, and the land surface temperature data obtained from (employed) a thermal band of Landsat 8 TIRS. The Landsat 8 data for the UM campus with Path 127 Row 058 in the year 2013 used data from $22 / 4 / 13,27 / 7 / 13,12 / 8 / 13,31 / 10 / 13$ and 16/11/13 and for the year 2014 used data from $4 / 2 / 14,8 / 3 / 14$, and 12/6/14. The Landsat 8 data for the UI campus with Path 122 Row 064 in the year 2013 used data from 22/6/13, 25/8/13, 10/9/13 and 26/9/13 and for the year 2014 used data from 9/6/14, 28/8/14, 13/9/14 and 29/9/14. The remainder of the source data obtained from http://glovis.usgs.gov/.

\subsection{Data Processes}

The generated data of land cover of both campuses obtained from Google Earth. Data collection and extraction started from downloaded satellite imagery from Google Earth (Park, 2009, Wibowo et al., 2016). The satellite image data from Google Earth was mosaicked using ArcGIS software. The result of the mosaicked images does not have geographic references. A georeferenced tool was used for the mosaicked images to obtain a georeferenced image based on Universal Transform Mercator (UTM) projection (Wibowo et al., 2016). Land cover types were obtained from Google Image Data by visual interpretation and digitalization was based on $10 \mathrm{~m} \times 10 \mathrm{~m}$ vector square grids with their attributes (Shim, 2014; Wibowo et al., 2015; Wibowo et al., 2016). To validate the land use cover data from Google Earth (survey). The data was saved in geodatabase storage and processed to produce a summary of the total area of each land cover type, set within standard symbols, colors and layout using ArcGIS with a cartographic standard as a land cover map (Wibowo et al., 2016).

The data processing is generated Land Surface Temperature using Equation 1 ( $\mathrm{L} \lambda=$ spectral radiance (wm-2sr-1 $\mu \mathrm{m}-1) ; \mathrm{M}=$ Multiplicative digital number value at band 10; DN of Band 10 $=$ Digital Number of Band 10 Landsat 8 OLI; A = Additive value of spectral radiance at band 10 according to http://landsat.usgs.gov/Landsat8_Using_Product.php). 


$$
L \lambda=(M * D N \text { of Band10 })+A
$$

Second, the spectral radiance resulting from equation 1 was converted to estimate the land surface temperature, following previous studies (Tursilowati et al., 2012; Wibowo et al., 2013; Wibowo et al., 2016). The formula represented in Equation 2.

$$
\text { Temp-KELVIN }=K 2 / \ln ((K l / L \lambda)+1)
$$

Temp-Kelvin is the estimation of land surface temperature from the satellite sensor with the temperature unit in Kelvin; $K 1$ is the calibration constant 1 for Landsat 8 OLI $\left(774.89 \mathrm{wm}^{-2} \mathrm{sr}^{-}\right.$ $\left.{ }^{1} \mathrm{~m}^{-1}\right) ; K 2$ is the calibration constant 2 for Landsat 8 OLI $(1321.08 \mathrm{~K})$, and $L \lambda$ is the spectral radiance of band 10 .

The final processing was a conversion from Kelvin to Celsius (Tursilowati et al., 2012; Wibowo et al., 2013) using Equation 3.

$$
\text { Temp-CELSIUS }=\text { Temp-KELVIN }-272.15=T-272.15
$$

Temp-Celsius is the land surface temperature with the standard for temperature in degrees Celsius, where $1^{\circ} \mathrm{K}$ is equivalent to $272^{\circ} \mathrm{C}$. The value of the urban heat signature uses temperatures in degrees Celsius $\left({ }^{\circ} \mathrm{C}\right)$. The land surface temperature value in degrees Celsius $\left({ }^{\circ} \mathrm{C}\right)$ based on the relationship between land-use/land-cover types and the heat emitted from their surfaces. (Kim \& Baik, 2005; Ichinose et al., 2008; Memon et al., 2009; Mirzaei \& Haghighat, 2010), and then defined as the Urban Heat Signature (UHS). The UHS explains the heat characteristics of certain land cover measured in different periods.

\subsection{Analysis}

Urban heat (Wong \& Yu, 2005; Srivanit \& Hokao, 2013), as the relationship between land cover types and sun radiation (Kim \& Baik, 2005; Ichinose et al., 2008; Memon et al., 2009; Mirzaei \& Haghighat, 2010). Remote Sensing (RS) and the Geographic Information System (GIS) were used in the research to explain the spatial-temporal variations in UHS. The analysis of the UHS was spatial-temporal; the spatial analysis used spatial pattern, density, and overlay between land cover and UHS and trend analysis to establish the temporal trends on both university campuses. The remaining results saw related to (a) land cover and its impact on the UHS of the university campuses using remote sensing.

\section{RESULTS AND DISCUSSION}

\subsection{Land cover at UM and UI campuses}

Land cover, as the localized urban environment on UM and UI campuses, can be seen in Table 1. About the comparative land cover of UM and UI, it found that the two urban campuses had a similar cover, but different total percentage areas. Land cover on the UM campus about building cover was $20.9 \%$ greater than on the UI campus, which had building cover of only $10.9 \%$. The UM campus was covered by $59.1 \%$ dense vegetation, which was lower than the UI campus cover of $65.3 \%$. The spatial distribution of land cover on the UM and UI campuses could see in Figure 1.

\subsection{Spatial-Temporal UHS on UM and UI campuses}

The spatial UHS pattern in 2013 and 2014 at UM could see in Figure 2, with color gradation from yellow to red (low to high temperature). Based on the spatial distribution of UHS on the UM campus, distribution of low temperatures was clustered in the middle and to the north of the campus, and high temperatures clustered to the south of the campus. 
Table 1 Land cover distribution on UM and UI campuses 2013-2014

\begin{tabular}{|c|c|c|c|c|c|}
\hline \multirow[b]{2}{*}{ No } & \multirow[b]{2}{*}{ Land cover } & \multicolumn{2}{|c|}{ UM campus } & \multicolumn{2}{|c|}{ UI campus } \\
\hline & & $\begin{array}{c}\text { Area } \\
\text { (ha) }\end{array}$ & $\begin{array}{l}\text { Percentage } \\
(\%)\end{array}$ & $\begin{array}{l}\text { Area } \\
\text { (ha) }\end{array}$ & $\begin{array}{l}\text { Percentage } \\
\quad(\%)\end{array}$ \\
\hline 1 & $\begin{array}{l}\text { Building cover (faculties, colleges, administrative } \\
\text { buildings) }\end{array}$ & 67.3 & 20.9 & 33.0 & 10.9 \\
\hline 2 & Paved open spaces & 52.9 & 16.4 & 35.8 & 12.6 \\
\hline 3 & Bodies of water & 3.0 & 0.9 & 22.9 & 7.5 \\
\hline 4 & $\begin{array}{l}\text { Open green surfaces (grassland, shrubs, isolated tree } \\
\text { strains) }\end{array}$ & 23.3 & 7.2 & 19.3 & 6.4 \\
\hline \multirow[t]{2}{*}{5} & Dense vegetated surfaces & 189.0 & 59.1 & 197.4 & 65.3 \\
\hline & & & 100.0 & & 100.0 \\
\hline
\end{tabular}
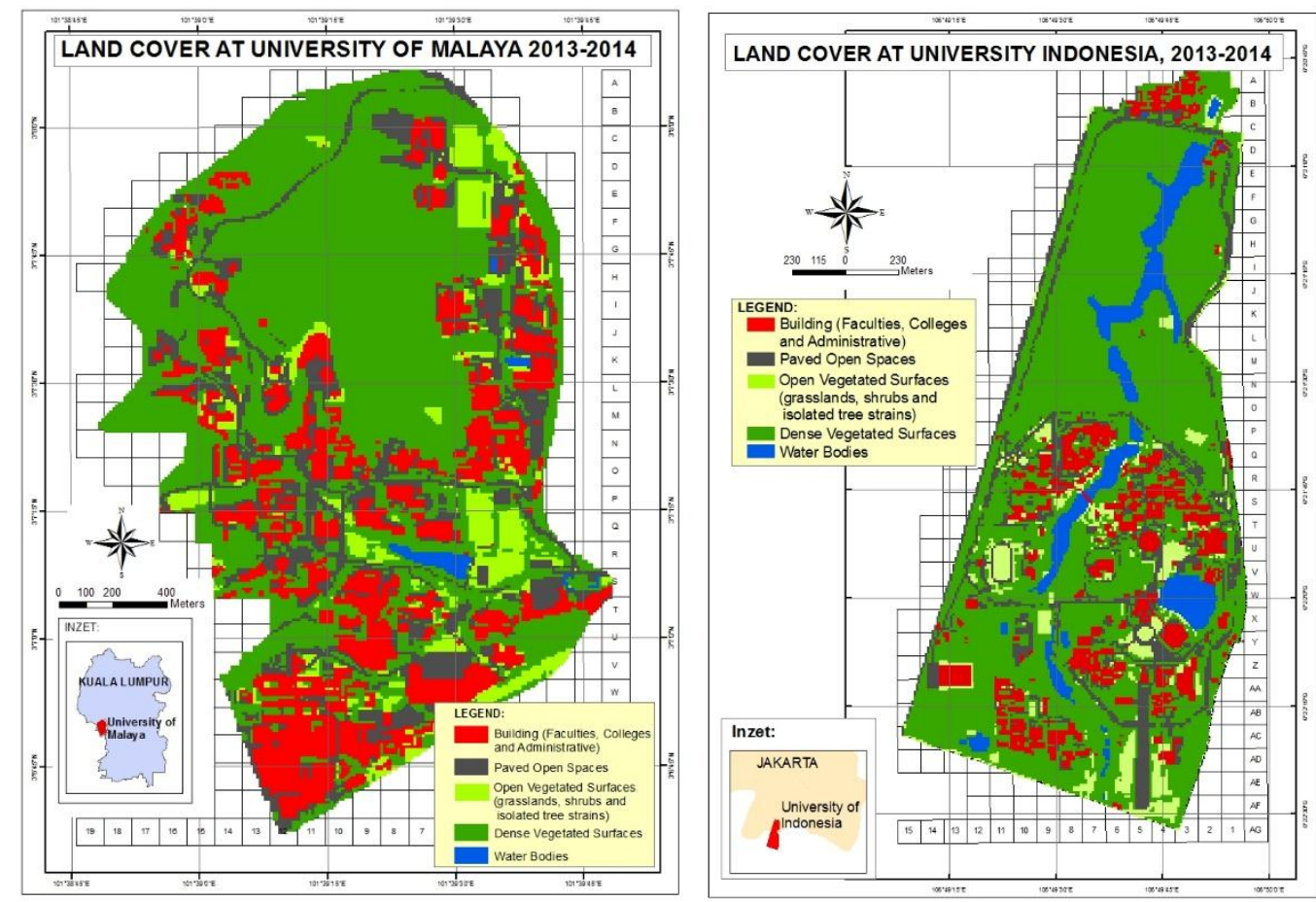

Figure 1 Spatial pattern land cover on UM and UI campuses

UHS in 2013 with low temperatures was very limited, while on the other hand red and yellowred colors were more dominant and distributed around the UM campus. Spatial distribution of UHS in 2014 was similar to that of 2013, but with very clear yellow in June 2014, with an area distribution covering more than $40 \%$ of the UM campus. The spatial density of UHS at UM is explained by the percentage of covered areas with high, moderate and low temperatures, as seen in Table 2. The spatial densities varied every month, depending on cloud cover. In general, the UM campus had moderate UHS cover most months.

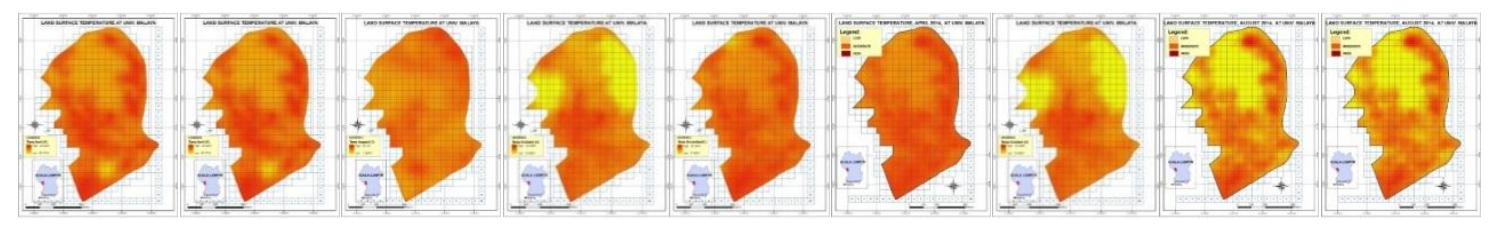

Figure 2 UHS spatial pattern 2013-2014 on the UM campus 
Table 2 Spatial density with percentage cover of UHS on the UM Campus

\begin{tabular}{rcrrrrrrrrr}
\hline \multirow{2}{*}{ No } & \multirow{2}{*}{ Urban Heat Signature } & Apr & Jul & Aug & Oct & Nov & Mar & Apr & Jun & Oct \\
& & 2013 & 2013 & 2013 & 2013 & 2013 & 2014 & 2014 & 2014 & 2014 \\
\hline 1 & Low & 23.5 & 32.6 & 44.4 & 20.5 & 5.5 & 37.5 & 23.6 & 53.6 & 43.0 \\
2 & Moderate & 49.9 & 60.0 & 48.0 & 38.7 & 47.7 & 56.1 & 35.6 & 43.1 & 32.5 \\
3 & High & 26.6 & 7.3 & 7.7 & 40.8 & 46.8 & 6.4 & 40.7 & 3.3 & 24.5 \\
\hline & Total & $100 \%$ & $100 \%$ & $100 \%$ & $100 \%$ & $100 \%$ & $100 \%$ & $100 \%$ & $100 \%$ & $100 \%$ \\
\hline
\end{tabular}

To understand the monthly land cover effect on the temporal UHS behavior on the UM campus could see in Figure 3. The behavior on the UM Campus in 2013 started on 22/4/2013 at 25 $31^{\circ} \mathrm{C}$; followed by $27 / 7 / 2013$ at $20-24^{\circ} \mathrm{C}$; $12 / 08 / 2013$ at $17-23^{\circ} \mathrm{C}, 31 / 10 / 2013$ at $20-31^{\circ} \mathrm{C}$; and $16 / 11 / 2013$ at $17-24^{\circ} \mathrm{C}$. The corresponding behavior on the UM campus in 2014 started on $4 / 2 / 14$ at $28-38^{\circ} \mathrm{C}, 8 / 3 / 14$ at $30-39^{\circ} \mathrm{C}, 12 / 6 / 14$ at $10-17^{\circ} \mathrm{C}$; and $15 / 10 / 14$ at $25-33^{\circ} \mathrm{C}$. These results show that UHS between 2013 and 2014 on the UM campus had a positive trend, with an average trend temperature $1^{\circ} \mathrm{C}$. The temporal trend for temperature maximum had a positive trend line $(\mathrm{y}=4.2745 \mathrm{x})$.

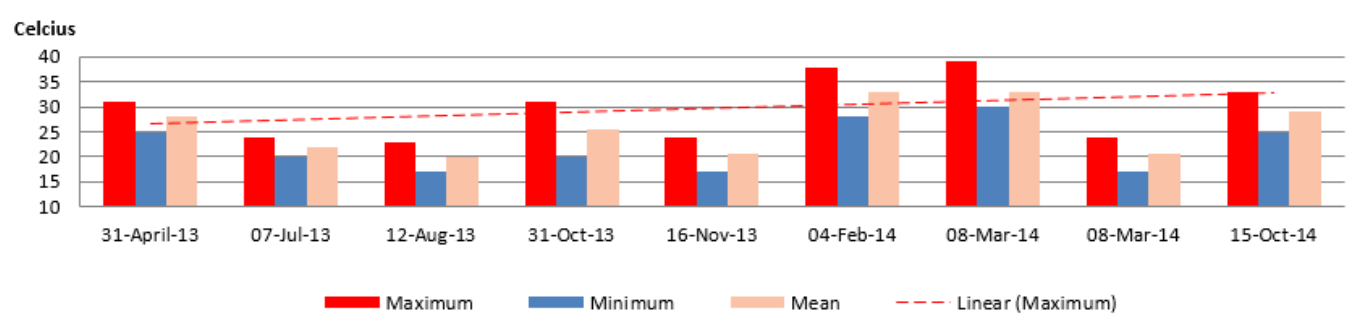

Figure 3 UHS behavior 2013-2014 on UM campus

The spatial UHS patterns in 2013 and 2014 on the UI campus could see in Figure 4. That figure shows a distribution of low temperatures clustered within the center of the north part of campus, and high temperatures clustered in the center and to the south. The spatial pattern of UHS in June 2013-2014 shows a small area with red and yellow color distribution around the campus; in August 2013-2014 there is a spatial distribution of red color clustered to the south of the campus in 2013, but in 2014 there is a distribution of yellow color around the campus. UHS with low temperatures dominated the spatial distribution in Sept/Oct 2013 and Sept 2014, with moderate temperature cover in June, August and Sept 2013, and Sept/Oct 2014. Furthermore, the red color had a dominating spatial distribution pattern in June 2014. The spatial density of UHS on the UI Campus could see in Table 3. In general, the UI campus had moderate UHS cover most months.

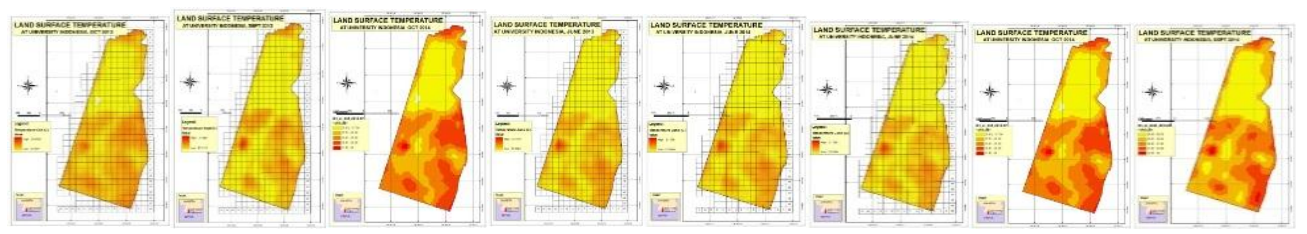

Figure 4 UHS spatial pattern 2013 and 2014 on UI campus

The temporal temperature of UHS on the UI campus in 2013 can be seen in Figure 5, which shows UHS behavior on $22 / 6 / 2013$ of $22-28^{\circ} \mathrm{C}$; on $25 / 8 / 2013$ of $26-32^{\circ} \mathrm{C}$; $10 / 9 / 13$ of $27-34^{\circ} \mathrm{C}$; and on $26 / 9 / 13$ of $27-34^{\circ} \mathrm{C}$. The corresponding behavior in 2014 was a UHS on $9 / 06 / 14$ of $20-$ $28^{\circ} \mathrm{C}$; on $28 / 08 / 14$ of $25-32^{\circ} \mathrm{C}$; on $13 / 09 / 14$ of $25-33^{\circ} \mathrm{C}$, and on $29 / 9 / 14$ of $21-33^{\circ} \mathrm{C}$. These results show that the UHS between 2013 and 2014 on the UM campus had a negative trend, 
with an average trend temperature of $1^{\circ} \mathrm{C}$. However, the maximum temporal trend was positive $(y=4.973 x)$.

Table 3 Spatial density with percentage UHS cover on UI Campus

\begin{tabular}{|c|c|c|c|c|c|c|c|c|c|}
\hline No & Urban Heat Signature & $\begin{array}{c}\text { Jun } \\
2013 \\
(\%)\end{array}$ & $\begin{array}{c}\text { Aug } \\
2013 \\
(\%)\end{array}$ & $\begin{array}{c}\text { Sep } \\
2013 \\
(\%)\end{array}$ & $\begin{array}{c}\text { Oct } \\
2013 \\
(\%)\end{array}$ & $\begin{array}{c}\text { Jun } \\
2014 \\
(\%)\end{array}$ & $\begin{array}{c}\text { Sep } \\
2014 \\
(\%)\end{array}$ & $\begin{array}{c}\text { Oct } \\
2014 \\
(\%)\end{array}$ & $\begin{array}{c}\text { Oct } \\
2014 \\
(\%)\end{array}$ \\
\hline 1 & Low & 12.9 & 28.4 & 34.6 & 57.6 & 16.4 & 51.0 & 26.4 & 26.4 \\
\hline 2 & Moderate & 46.4 & 43.0 & 47.9 & 37.3 & 33.8 & 46.5 & 56.0 & 56.0 \\
\hline \multirow[t]{2}{*}{3} & High & 40.7 & 28.6 & 17.5 & 5.1 & 49.7 & 2.5 & 17.6 & 17.6 \\
\hline & Percentage & 100 & 100 & 100 & 100 & 100 & 100 & 100 & 100 \\
\hline
\end{tabular}

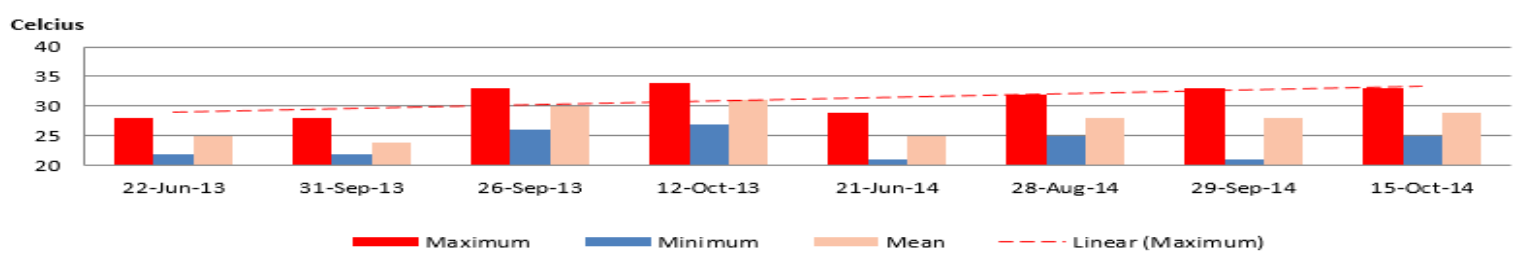

Figure 5 UHS behavior 2013-2014 on UI campus

\subsection{Land Cover and its Impact on UHS on the UM and UI Campuses}

The localized urban environment represented by land cover types had different heat signatures within the urban areas. The UHS in UM campus is corresponding to paved open spaces with a mean of $21.6-35.1^{\circ} \mathrm{C}$, building cover with a mean of $27.0-35.3^{\circ} \mathrm{C}$, waterbody cover with a mean of $26.5-33.7^{\circ} \mathrm{C}$, open vegetation cover with a mean of $25.6-34.7^{\circ} \mathrm{C}$ and dense vegetation cover with a mean of $25.9-32.8^{\circ} \mathrm{C}$ (Table 4 ).

Table 4 Land cover and its impact on UHS on the UM campus 2013-2014

\begin{tabular}{|c|c|c|c|c|c|c|c|c|c|c|c|c|}
\hline \multirow[b]{2}{*}{$\begin{array}{l}\text { Land Cover } \\
\text { Type }\end{array}$} & \multicolumn{3}{|c|}{ UHS April $2013\left({ }^{\circ} \mathrm{C}\right)$} & \multicolumn{3}{|c|}{ UHS Oct $2013\left({ }^{\circ} \mathrm{C}\right)$} & \multicolumn{3}{|c|}{ UHS Feb $2014\left({ }^{\circ} \mathrm{C}\right)$} & \multicolumn{3}{|c|}{ UHS March $2014\left({ }^{\circ} \mathrm{C}\right)$} \\
\hline & Min & Max & Mean & Min & Max & Mean & Min & $\operatorname{Max}$ & Mean & Min & Max & Mean \\
\hline $\begin{array}{l}\text { Paved Open } \\
\text { Space }\end{array}$ & 25.0 & 31.0 & 29.2 & 21.6 & 31.0 & 26.3 & 29.0 & 38.0 & 34.8 & 30.0 & 39.0 & 35.1 \\
\hline $\begin{array}{l}\text { Building } \\
\text { Cover }\end{array}$ & 25.0 & 31.0 & 29.4 & 22.0 & 32.0 & 27.0 & 30.0 & 38.0 & 35.1 & 31.0 & 39.0 & 35.3 \\
\hline $\begin{array}{l}\text { Open Veg. } \\
\text { Surfaces }\end{array}$ & 25.0 & 31.0 & 28.7 & 20.0 & 31.0 & 25.6 & 29.0 & 37.0 & 34.6 & 31.0 & 37.0 & 34.6 \\
\hline $\begin{array}{l}\text { Bodies of } \\
\text { Water }\end{array}$ & 28.0 & 30.0 & 28.6 & 21.0 & 32.0 & 26.5 & 33.0 & 36.0 & 33.7 & 33.0 & 36.0 & 33.7 \\
\hline $\begin{array}{l}\text { Dense Veg. } \\
\text { Surfaces }\end{array}$ & 25.0 & 31.0 & 28.1 & 20.9 & 31.0 & 25.9 & 28.0 & 38.0 & 32.8 & 30.0 & 39.0 & 32.8 \\
\hline
\end{tabular}

The UI campus had different results to the UM campus. The UHS on the UI campus corresponding to paved open spaces had a mean of $27.0-34.8^{\circ} \mathrm{C}$; building cover a mean of 29.4$35.1^{\circ} \mathrm{C}$; waterbody cover one of $28.1-33.7^{\circ} \mathrm{C}$; open vegetation cover a mean of $28.7-34.6^{\circ} \mathrm{C}$, and dense vegetation cover had a mean of $27.6-32.8^{\circ} \mathrm{C}$ (Table 5).

Comparative land cover by buildings on the UM campus was $20.9 \%$, higher than on the UI campus, which was only $10.9 \%$. The UM campus was covered by $59.1 \%$, of dense vegetation, while the UI campus had coverage of $65.3 \%$. Both universities had urban areas (building cover and paved open spaces) with a total area of more than 20\%. This result relates to previous studies, in that urban areas can generate urban heat (Wong \& Yu, 2005; Ahmad \& Hashim, 
2007; Tursilowati et al., 2012; Wibowo et al., 2013). Furthermore, the land cover type is a representation of land use (Asmat et al., 2003; Ren et al., 2012, Lenzholzer \& Brown, 2013; Steeneveld et al., 2014).

Table 5 Land cover and its impact on UHS on the UI campus 2013-2014

\begin{tabular}{|c|c|c|c|c|c|c|c|c|c|c|c|c|}
\hline \multirow{2}{*}{ Land Cover Type } & \multicolumn{3}{|c|}{ UHS Jun $2013\left({ }^{\circ} \mathrm{C}\right)$} & \multicolumn{3}{|c|}{ UHS Sep $2013\left({ }^{\circ} \mathrm{C}\right)$} & \multicolumn{3}{|c|}{ UHS May $2014\left({ }^{\circ} \mathrm{C}\right)$} & \multicolumn{3}{|c|}{ UHS Sep $2014\left({ }^{\circ} \mathrm{C}\right)$} \\
\hline & Min & Max & Mean & Min & Max & Mean & Min & $\operatorname{Max}$ & Mean & Min & $\operatorname{Max}$ & Mean \\
\hline & 25.0 & $\overline{31.0}$ & 292 & 28.0 & $\overline{35.0}$ & 311 & $\overline{29.0}$ & 38.0 & 34.8 & 20.0 & $\overline{34.0}$ & 27.0 \\
\hline & & & & & & & & & & & & \\
\hline & & & & 28.0 & & & & 37. & & 22.0 & & 28.8 \\
\hline & 28.0 & 30.0 & 28.6 & 28.0 & 32.0 & 29 & 33.0 & 36.0 & 33.7 & 27.0 & 31.0 & 28.1 \\
\hline Dense Veg. Surfaces & 25.0 & 31.0 & 28.1 & 28.0 & 34.0 & 29.9 & 28.0 & 38.0 & 32.8 & 22.0 & 33.0 & 27.6 \\
\hline
\end{tabular}

Spatial UHS distribution in 2014 was similar to that of 2013, except that in June 2014 the highest temperature area distribution covered more than $40 \%$ of the UM campus. In general, moderate UHS temperatures occurred most months on the UM campus. In the study area of the UI campus, the UHS included more than $40 \%$ of low temperatures in the spatial distribution in September 2013 and September 2014. In general, moderate temperatures were recorded in 2013 (June, August, \& September) and September 2014, apart from June 2014, highest temperature distributed as a spatial pattern related to land cover. The temporal UHS behavior on the UM campus between April and November 2013 showed temperatures between $17^{\circ} \mathrm{C}$ and $31^{\circ} \mathrm{C}$, with an average of $24^{\circ} \mathrm{C}$, and UHS behavior between $\mathrm{Feb}$ and October 2014 with temperatures between $10^{\circ} \mathrm{C}$ and $39^{\circ} \mathrm{C}$ and an average of $25^{\circ} \mathrm{C}$. For the UI campus, temporal UHS behavior between June and September 2013 showed temperatures between $22^{\circ} \mathrm{C}$ and $34^{\circ} \mathrm{C}$, with an average of $28^{\circ} \mathrm{C}$, and UHS behavior between June and September 2014 with temperatures between $20^{\circ} \mathrm{C}$ and $33^{\circ} \mathrm{C}$, with an average of $27^{\circ} \mathrm{C}$. The UHS behavior in 2013-2014 was different, and this phenomenon relationship between land cover types and solar radiation. (Taha, 1997; Asmat et al., 2003; Wong \& Yu, 2005; Mirzaei \& Haghighat, 2010; Ren et al., 2012; Srivanit \& Hokao, 2013; Lenzholzer \& Brown, 2013). The variation in spatial density every month depended on cloud cover in the area of study, is a limitation of the work with satellite data. The results showed that the UHS between 2013 and 2014 on the UM and UI campuses had a positive trend, with an average temperature of $10^{\circ} \mathrm{C}$; the maximum temporal trend was positive, at $\mathrm{y}=4.2745 \mathrm{x}$, on the UM campus, and also positive, at $\mathrm{y}=4.973 \mathrm{x}$, on the UI campus. The increasing trend UHS $1^{\circ} \mathrm{C}$ on both campuses, which is related to previous studies, which have noted temperature increases of $0.5^{\circ} \mathrm{C}$ to $1.5^{\circ} \mathrm{C}$, in line with the intensity of land use change (Malaysian Meteorological Department, 2009).

Urban heat studies conclude that areas with high surface temperatures $\left(>30^{\circ} \mathrm{C}\right)$ are mostly seen in central parts of cities (less vegetated), with lower temperatures found in vegetated (suburban) and areas with bodies of water (Tursilowati et al., 2012). Other research has obtained results that show that higher vegetation cover as the land cover type (Skelhorn et al. 2014) is related to low temperatures (Sham 1979; Taha 1997; Tran et al., 2006: Wong et al., 2007; Wong \& Jusuf 2008; Srivanit \& Hokao 2013). The final result shows the UHS behavior in 2013-2014 on both campuses as the impact from land cover and solar radiation with a mean temperature for building a cover on the UM campus of $27.0-35.3^{\circ} \mathrm{C}$. Th another hand a mean temperature on the UI campus of $29.4-35.1^{\circ} \mathrm{C}$, paved open spaces on the UM campus of $26.3-35.1^{\circ} \mathrm{C}$ and the UI campus of $27.0-34.8^{\circ} \mathrm{C}$. Both land cover types had an impact on UHS behavior with the highest temperatures. These results relate to previous studies, which have shown that land cover causes urban heat (Taha, 1997; Asmat et al., 2003; Wong \& Yu, 2005; Mirzaei \& Haghighat, 2010; Ren et al., 2012; Srivanit \& Hokao, 2013; Lenzholzer \& Brown, 2013). The new finding that 
land cover affects UHS for every land cover type on the university campuses of small cities had differentiated temperature as a localized urban environment.

Despite the relation between UHS and land cover type, further research into land cover and its effect on localized urban areas could conduct. In particular, different influences on land cover types, including cloud cover and temporal data (longitudinal), need to be studied further. Unfortunately, the LST reason behind this finding remains unsolved and is open to further study. Finally, this research does not examine climate change and sustainability. In the 20132014 period, when the warmest month with the highest UHS as impact land cover in the study area, and thus a less cooling or warming effect on the air temperature during the day is open for further study of UHS.

\section{CONCLUSION}

Based on Landsat 8 TIRS (100 m ground resolution) the result on both university campuses had UHS related to vegetation cover of $25-33^{\circ} \mathrm{C}$ with a mean of $28^{\circ} \mathrm{C}$ as the lowest temperature. The building covered $33-39^{\circ} \mathrm{C}$ with a mean of $35^{\circ} \mathrm{C}$ as the highest temperature, its effect on land cover types likes build-up area. Google Earth provided the land cover for visual interpretation, and digitalization based on a $10 \mathrm{~m} \times 10 \mathrm{~m}$ vector square grid with their attribute and land cover attribute validated with field survey.

Our research has shown the critical trend of UHS change in the period 2013-2014, with a maximum temperature of $>30^{\circ} \mathrm{C}$ on the UM and UI campuses increased in temperature with $1^{\circ} \mathrm{C}$. Finally, this study has concluded that UHS behavior is an effect of the temporal relation between land cover and solar radiation. The new knowledge for university campuses UHS is relation land cover with solar energy in the localized urban environment.

\section{ACKNOWLEDGMENT}

This research support by Department of Geography, Faculty of Mathematics and Natural Sciences, Universitas Indonesia.

\section{REFERENCES}

Ahmad, S., Hashim, N.M., 2007. Effect of Soil Moisture on Urban Heat Island Occurrences: Case of Selangor, Malaysia. Humanity \& Social Sciences Journal, Volume 29(2), pp. 132138

Asmat. A., Mansor S., Hong W.T., 2003. Rule-Based Classification for Urban Heat Island Mapping. 2nd Fig Regional Conference Marrakech, pp. 1-11

Chen, L., Ng, E., 2012. Outdoor Thermal Comfort and Outdoor Activities: A Review of Research in the Past Decade. Cities, Volume 29(2), pp. 118-125

de la Barrera, F., Pecke, S.R., Banzhaf, E., 2015. Indicators for Green Spaces in Contrasting Urban Settings. Ecology Indicator, Volume 62, pp. 212-219

Gartland, L., 2008. Heat Island: Understanding and Mitigating a Heat in Urban Area. Earthscan

Ichinose, T., Matsumoto, F., Kataoka, K., 2008. Urban Thermal Environment and its Mitigation through the Urban Planning Process. Geographical Reports of Tokyo Metropolitan University, Volume 43, pp. 33-40

Johnson, D.P., Stanforth, A., Lula V., Luber, G., 2012. Developing an Applied Extreme Heat Vulnerability Index Utilizing Socioeconomic and Environmental Data. Applied Geography, Volume 35(1), pp. 23-31

Kim, Y.H., Baik, J.J., 2005. Spatial and Temporal Structure of the Urban Heat Island in Seoul. Journal American Meteorological Society, Volume 44(5), pp. 591-605 
Kuşcu, C., Sengezer, B., 2011. Determination of Heat Islands from Landsat TM Data: Relationship between Surface Temperature and Urbanization Factors in Istanbul, the GEOSS Era: Towards Operational Environmental Monitoring: International Symposium on Remote Sensing of Environment

Lenzholzer, S., Brown, R.D., 2013. Climate-responsive Landscape Architecture Design Education. Journal of Cleaner Production, Volume 61, pp. 89-99

Li, S., Zhao, Z., Miaomiao, X., Wang, Y., 2010. Investigating Spatial Non-stationary and Scaledependent Relationships between Urban Surface Temperature and Environmental Factors using Geographically Weighted Regression. Environmental Modelling \& Software, Volume 25(12), pp. 1789-1800

Makaremi, N., Salleh, E., Jaafar, M.Z., GhafarianHoseini, A., 2012. Thermal Comfort Conditions of Shaded Outdoor Spaces in Hot and Humid Climate of Malaysia. Building and Environment, Volume 48, pp. 7-14

Malaysian Meteorological Department, 2009. Climate Change Scenarios For Malaysia 20012099. Numerical Weather Prediction Development Section, Technical Development Division Malaysian Meteorological Department, Ministry of Science, Technology, and Innovation

Mallick, J., Singh, C.K., Shashtri, S., Rahman A., Mukherjee, S., 2012. Land Surface Emissivity Retrieval based on Moisture Index from LANDSAT TM Satellite Data Over Heterogeneous Surfaces of Delhi City. International Journal of Applied Earth Observation and Geoformation, Volume 19, pp. 348-358

Memon, R.A., Leung, D.Y., Liu, C.H., 2009. An Investigation of Urban Heat Island Intensity (UHII) as an Indicator of Urban Heating. Journal of Atmospheric Research, Volume 94(3), pp. 491-500

Mirzaei, P.A., Haghighat, F., 2010. Approach to Study Urban Heat Island-abilities and Limitation. Journal of Building and Environment, Volume 45(10), pp. 2192-2201

Park, L., 2009. Digging into Google Earth: An analysis of "Crisis in Darfur". GEOFORUM, Volume 40(4) pp. 535-545

Ren, C., Spit, T., Lenzholzer, S., Yim, H.L.S., Heusinkveld, B., van Hove, B., Chen, L., Kupski, S., Burghardt, R., Katzschner, L., 2012. Urban Climate Map System for Dutch Spatial Planning. International Journal of Applied Earth Observation and Geoinformation, Volume 18, pp. 207-221

Roy, D.P., Wulder, M.A., Loveland, T.R., Woodcock, C.E., Allen, R.G., Anderson, M.C., Zhu, Z., 2014. Remote Sensing of Environment, Volume 145, pp. 154-172

Rozenstein, O., Qin, Z., Yevgeny D., Arnon, K., 2014. Derivation of Land Surface Temperature for Landsat-8 TIRS using a Split Window Algorithm. Sensors, Volume 14(4), pp. 57685780

Saadatian, O., Sopian, K.B., Salleh, E., 2013. Adaptation of Sustainability Community Indicators for Malaysian Campuses as Small Cities. Journal Sustainable Cities and Society, Volume 6, pp. 40-50

Salleh, K.O., Gaffar, F.A., 2009. Vulnerability and Adaptation to the Climate Change Threat: Issues and Challenges for Malaysia. International Conference on Climate Change: Impacts and Responses

Senanayake, I.P., Welivitiya, W.D.D.P., Naadeka, P.M., 2013. Remote Sensing Based Analysis of Urban Heat Islands with Vegetation Cover in Colombo City, Sri Lanka using Landsat-7 ETM+ Data. Urban Climate, Volume 5, pp. 19-35

Shahidan, M.F., Phillip, J.J., Julie, G., Salleh, E., 2012. An Evaluation of Outdoor and Building Environment Cooling Achieved Through Combination Modification of Trees with Ground Materials. Building and Environment, Volume 58, pp. 245-257 
Sham, S, 1979. Effect of Urbanization on Climate with Special Reference to Temperature in the Kuala Lumpur-Petaling Jaya Area Malaysia

Shim, D., 2014. Remote Sensing Place: Satellite Images as Visual Spatial Imaginaries, GEOFORUM, Volume 51, pp. 152-160

Skelhorn, C., Lindley, S., Levermore, G., 2014. The Impact of Vegetation Types on Air and Surface Temps in a Temperate City: A fine Scale Assessment in Manchester, UK. Landscape and Urban Planning, Volume 121, pp. 129-140

Srivanit, M., Hokao, K., 2013. Evaluating the Cooling Effects of Greening for Improving the Outdoor Thermal Environmental an Institutional Campus in the Summer. Building and Environment, Volume 66, pp. 158-172

Srivastava, P.K., Majumdar, T.J., Bhattacharya, A.K., 2009. Surface Temperature Estimation in Singhbhum Shear Zone of India using Landsat-7 ETM+ Thermal Infrared Data. Advances in Space Research, Volume 43(10), pp. 1563-1574

Steeneveld, G.J., Koopmans, S., Heusinkveld, B.G, Theeuwes, N.E., 2014. Refreshing the Role of Open Water Surfaces on Mitigating the Maximum Urban Heat Island Effect. Landscape and Urban Planning, Volume 121, pp. 92-96

Stewart, I.D., Oke, T.R., 2012. Local Climate Zones for Urban Temp Studies. American Meteorological Society. Meteor. Volume 93, pp. 1879-1900

$\mathrm{Su}$, Y.F., Foody, G.M., Cheng, K.S., 2012. Spatial Non-stationarity in the Relationships between Land Cover and Surface Temperature in an Urban Heat Island and its Impacts on Thermally Sensitive Populations. Landscape and Urban Planning, Volume 107(2), pp. $172-180$

Suwartha, N., Sari, R.F., 2013. Evaluating UI Green Metric as a Tool to Support Green Universities Development: Assessment of the year 2011 Ranking. Journal of Cleaner Production, Volume 61, pp. 46-53

Taha, H., 1997. Urban Climates and Heat Islands: Albedo, Evapotranspiration, and Anthropogenic Heat. Energy and Buildings, Volume 25(2), pp. 99-103

Tran, H., Daisuke, U., Shiro, O., Yoshifumi, Y., 2006. Assessment with Satellite Data of the Urban Heat Island Effects in Asian Mega Cities. International Journal of Applied Earth Observation and Geo-information, Volume 8(1), pp. 34-48

Tursilowati, L., 2008. Urban Heat Island and Their Contribution on Climate Change and Relationship with Land Use Change. In: Proceeding National Seminar on Global Warming and Global Change: Fact, Mitigation, and Adaptation. ISBN: 978-979-17490-0-8

Tursilowati, L., Sumantyo, J.T.S., Kuze, H., Adiningsih, E.S., 2012. Relationship between Urban Heat Island Phenomenon and Land Use/Land Cover Changes in Jakarta, Indonesia. Journal of Emerging Trends in Engineering and Applied Sciences, Volume 3(4), pp. 645653

Wang, Y., Shi, H., Sun, M., Huising, D., Hanson, L., Wang, R., 2013. Moving Toward an Ecology Sound Society? Starting from Green Universities and Environmental Higher Education. Journal of Cleaner Production, 61, pp. 1-5

Wang, F., Qin, Z., Karnieli, A., Song, C., Tu, L., Zhao, S., 2015. An Improved Monowindow Algorithm for Land Surface Temperature Retrieval from Landsat 8 Thermal Infrared Sensor Data. Remote Sensing, Volume 7(4), pp. 4269-4289

Wang, S., Ding, H., Liang, H., Ma, Q., 2016. Detection of Urban Expansion and Land Surface Temperature Change using Multi-temporal Landsat Image. Resources, Conservation and Recycling, Volume 128, pp. 526-534

Weng, Q., Fu, P., Gao, F., 2014. Generating Daily Land Surface Temperature at Landsat Resolution by Fusing Landsat and MODIS Data. Remote Sensing of Environment, Volume 145 , pp. 55-67 
Wibowo, A., Raditya, A., Harmantyo, D., Semedi, J.M., 2015. Land Surface Temperature as Urban Hazard in Education Area (A Case Study: University of Indonesia). In: Proceeding the First International Conference of Indonesian Society for Remote Sensing, Indonesia

Wibowo, A., Rustanto, A., Shidiq, I.P.A., 2013. Spatial-temporal Analysis of Urban Heat Island in Tangerang City. Indonesian Journal of Geography, Volume 45(2), pp. 101-112

Wibowo, A., Salleh, K.O., Frans, F.Th.R S., Semedi, J.M., 2016. Spatial Temporal Land Use Change Detection using Google Earth Data. IOP Conf. Ser.: Earth Environ. Sci. 47012031

Wong, N.H., Jusuf, S.K., 2008. GIS-based Greenery Evaluation on Campus Master Plan. Landscape and Urban Planning, Volume 84(2), pp. 166-182

Wong, N.H., Jusuf, S.K., La Win, A.A., Thu, H.K., Syatia, T., Xuchou, W., 2007. Environmental Study of the Impact of Greenery in an Institutional Campus in the Tropics. Journal of Building and Environment, Volume 42(8), pp. 2949-2970

Wong, N.H., Yu, C., 2005. Study of Green Areas and Urban Heat Island in a Tropical City. Journal of Habitat International, Volume 29(3), pp. 547-558 